\title{
Non-invasive analysis and visualization of objects from FSW AISi9Mg/2017A aluminum alloy joints
}

\author{
Nieinwazyjna analiza i wizualizacja obiektów \\ w złączach AlSi9Mg/2017A \\ wytwarzanych metodą Friction Stir Welding
}

\begin{abstract}
Friction stir welding (FSW) technology allows for the welding of materials that differ in their chemical compositions, microstructures, and properties. When selecting the parameters, it is necessary to analyze the structure of a weld and eliminate the defects. The use of X-ray microtomography creates the possibility of precise imaging of a joint structure - especially when it contains defects (voids). The tests were carried out on an FSW joint made with both 2017A and AISi9Mg aluminum alloys.

The macrostructure was cross-sectional, and a defect was found in the middle part of the joint and on the advancing side. We used a conventional method of observation light microscopy. Then, an analysis was performed using X-ray microtomography, which revealed the shape of the defect in 3D. Individual cross-sections were extracted, which enabled us to measure the geometric quantities. A dependence was found for the shape of the defect on the welding parameters and the variability of its construction. The usefulness of this advanced material imaging technology for the analysis of FSW welds has been confirmed.
\end{abstract}

Keywords: X-ray microtomography, image analysis, aluminum alloys, FSW

\section{Streszczenie}

Technologia FSW umożliwia zgrzewanie materiałów różniących się składem chemicznym, mikrostrukturą i właściwościami. Przy doborze parametrów konieczna jest analiza struktury złącza i eliminacja ewentualnych wad. Zastosowanie mikrotomografii komputerowej umożliwia precyzyjne obrazowanie budowy złącza, szczególnie gdy zawiera wady (pustki). Badania przeprowadzono na złączu FSW stopów aluminium 2017A i AISi9Mg. Zbadano makrostrukturę na przekroju poprzecznym i stwierdzono obecność wady w środkowej części złącza i po stronie natarcia. Zastosowano konwencjonalną metodę obserwacji - mikroskopię świetlną. Następnie wykonano analizę złącza z zastosowaniem tomografii komputerowej, która ujawniła kształt wady w wymiarze 3D. Wyekstrahowano poszczególne przekroje, które umożliwiły wykonanie pomiarów wielkości geometrycznych. Stwierdzono zależność kształtu wady od parametrów zgrzewania oraz zmienność jej

Anna Wójcicka, Krzysztof Mroczka, Marcin Kowalski: Department of Technology and Engineering of Material, Institute of Technology, Pedagogical University of Cracow, Poland; anna.wojcicka@up.krakow.pl 
budowy. Potwierdzono przydatność tej zaawansowanej technologii obrazowania budowy materiałów do analizy złącz FSW.

Słowa kluczowe: mikrotomografia komputerowa, analiza obrazów, stopy aluminium, FSW

\section{Introduction}

The basis of the FSW method is plastic deformation caused by a suitably profiled tool. The effectiveness of welding (i.e., the production of a joint of an appropriate quality) depends on many factors. It is influenced by the welding parameters, type of tool, position of the materials in the joint (in the case of dissimilar weld seams), etc. [1, 2]. One of the difficulties with the FSW process is that each of these factors has a major impact on the quality of a joint. For these reasons, their selection is often difficult, and the joint must be tested for defects.

The most common defects in FSW joints include voids (no material filling) on the advancing side (i.e., on the side of a joint where the material is pushed out before the tool is due to its rotational and linear movement) [3-5].

In the case of very unfavorable flow conditions during welding, the defect may expand into the larger part of the joint - towards the retreating side in the middle or bottom part of the joint.

In turn, one of the basic advantages of the FSW method is the ability to perform different welds, even with such materials that differ significantly in their melting points and other properties (such as Al-steel [6] and Al-Ti [7]). In the literature on the subject, there are many works on the research on FSW welding of light alloys [8] (including various aluminum alloys) $[9,10]$. The difficulty in this area lies in the choice of conditions that take into account the plastic properties of a given material at elevated temperatures $\left(450-530^{\circ} \mathrm{C}\right)$ and dynamic deformations [11]. Still, other conditions must be chosen when alloys featuring significantly different microstructures are welded; e.g., cast alloy with wrought alloys. To avoid defects, moving the welding line offset into one of the alloys can be applied [12].

In order to determine the quality and construction of a joint, classic metallographic tests involving observation of the cross-section to the welding direction are usually performed. For obtaining full information on the structure of a joint, it is necessary to study longitudinal sections - many layers [13]. An alternative to this are studies using X-ray microtomography $[14,15]$. Presented below are the results of the analysis in which a defect was found using this technique of imaging the material structure.

\section{Experimental method}

In the experiment, 2017A-T451 and AISi9Mg aluminum alloys were used in the form of a sheet and a plate, respectively - each with a thickness of $6 \mathrm{~mm}$. The chemical composition of the alloys is presented in Table 1. 
Table 1. Chemical compositions of 2017A and AlSi9Mg alloys [wt.\%]

\begin{tabular}{|c|c|c|c|c|c|c|}
\cline { 2 - 7 } \multicolumn{1}{c|}{} & Cu & Mg & Mn & Si & Zn & Fe \\
\hline 2017A & 4.14 & 0.72 & 0.6 & 0.68 & 0.18 & 0.31 \\
\hline AISi9Mg & 0.21 & 0.31 & 0.34 & 8.6 & 0.14 & 0.64 \\
\hline
\end{tabular}

The material was subjected to the FSW process with the following parameters: a rotation rate of $560 \mathrm{rpm}$, and a linear velocity of the tool of $560 \mathrm{~mm} / \mathrm{min}$. The welding process was performed with the use of a conventional tool: a threaded pin with a diameter of $8 \mathrm{~mm}$, and a shoulder with a diameter of $22 \mathrm{~mm}$. The FSW was performed at the Institute of Welding in Gliwice, Poland.

The microstructure investigations were conducted with the use of an OLYMPUS GX51 optical microscope with optical instrumentation. The microscopic observations were performed on a cross-section perpendicular to the surface of the weld. To create the panorama of the macrostructure of the sample, Microsoft Image Composite Editor (ICE) was used, which enabled us to constitute a composition of several images of light microscopy. The X-ray microtomography studies were performed by a laboratory X-ray Microtomography scanner (v|tome|x s, GE Sensing \& Inspection Technologies, Phoenix|X-ray, Wunstorf, Germany) using $140 \mathrm{kV}$ voltage, a $78-\mu \mathrm{A}$ current, 250-ms detector timing, and a $0.1-\mathrm{mm} \mathrm{Cu}$ filter. The dataset reconstructed by filtered back projection consisted of a $411 \times 380 \times 1010$ isotropic voxel size equal to $18.262 \mu \mathrm{m}$ stored on a single raw file in the 8 -bit range of gray values $(0-255)$ and was processed by Drishti software.

\section{Results and discussion}

Our studies on the structures of the FSW welds started from an analysis of the macrostructure of the conventional method: by performing a cross-section perpendicular to the face of the weld and performing metallographic observations. An image of a single macrostructure cross section of the weld (within a range that included the center of the weld portion) is shown in Figure 1. A detailed analysis was made possible by obtaining an image macro (the entire weld) on the basis of 96 microscopic images made with a light microscope. A weld made in the system (the AISi9Mg aluminum alloy) is located at the advancing side (left side of Figure 1) and, accordingly, the 2017A alloy on the retreating side.

On the basis of the microstructure, it can be seen that there is the disadvantage of a complex shape of the central portion of the weld in the analyzed cross-section. The defect is located in the middle of the weld and (mostly) on the retreating side - in the alloy with a higher strength at room temperature (i.e., 2017A). The place where the defect is observed is often identified as critical for FSW welds; this is related to the flow of material as a result of the movement of the FSW tool - the material is moved around the tool and 
placed at the retreating side. The result of the absence of adequate quantities of material transported in the direction of the retreating side may feature insufficient plasticity; this leads to create defects that are visible in the cross section. The conditions giving rise to the defects need not be maintained during the entire welding process, and their modification may change the nature of the defects (including its size). To determine the shape of the defect, there should be a large number of transverse or longitudinal sections in the direction of the welding. The alternative to such labor-intensive research and not giving a complete picture of the changes in the construction of a weld (non-continuous observation - only on selected sections) is to use microtomography analysis.

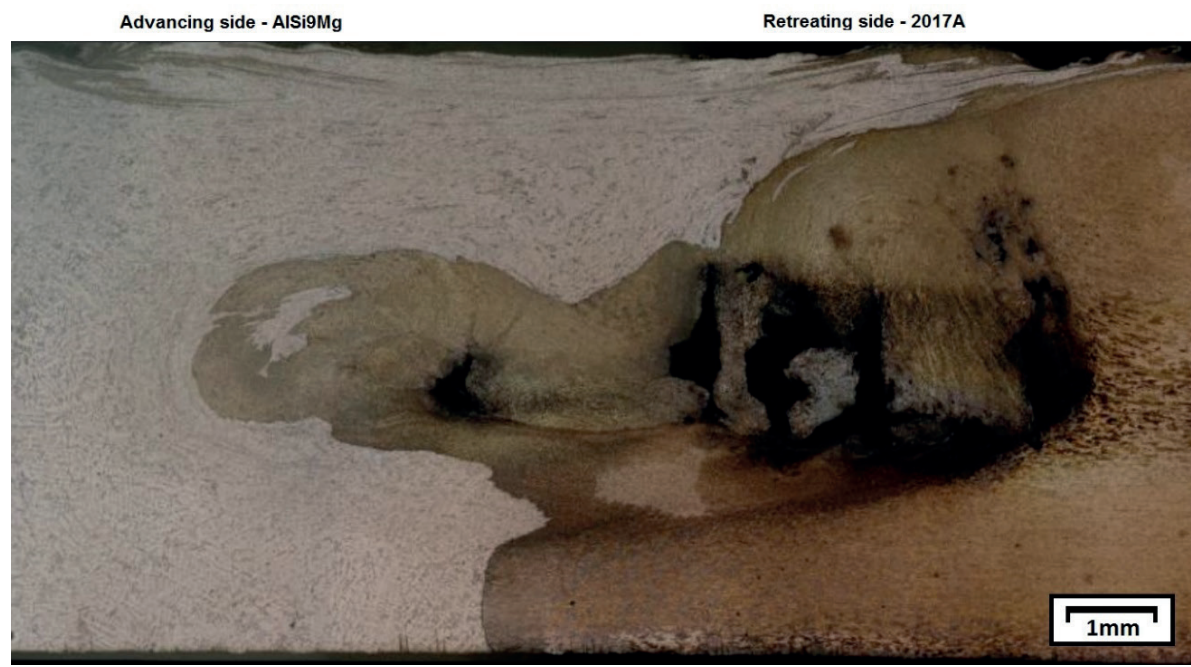

Fig. 1. Single macrostructure cross section of AlSi9Mg/2017A weld (within range including center of weld portion)

Microtomography research is a complex process; it involves a first phase-performed scan of an object to give a series of two-dimensional projections - for further processing. This two-dimensional projection was use to made three-dimensional model

A three-dimensional model of the FSW joint was make from two-dimensional projection by Drishti software [16]; this provided information on the location, changes in the shape, and geometry of the microstructure along the main direction of the movement of the tool. This is possible, since the test object in the weld (i.e., the defect) has a completely different density when compared to the density of the metallic material.

Figure 2 shows a three-dimensional model of the sample. Due to the difference in the density of the structural components present in the material forming the weld, there is a clear difference between the AISi9Mg and 2017A alloys. Due to the higher content of $\mathrm{Cu}$ and Fe having a high coefficient of density, the 2017A material assumes lighter shades 
of gray. In turn, the cast alloy (AISi9Mg) shows shrinkage porosity that is clearly marked; this arises in the process of casting the material and the segregation of elements.

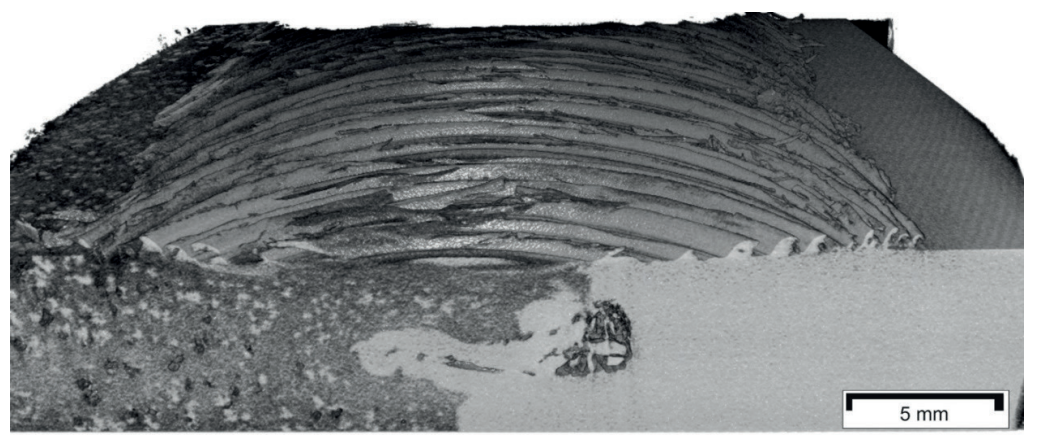

Fig. 2. Three-dimensional model of ALSi9Mg/2017A weld

Clearly visible grooves on the face of the weld are formed after the passage of the shoulder of the FSW tool. The tool mixing the material from the retreating side to the advancing side. Thus, the use of microtomography allows us to observe the external surface of the weld.

The primary advantage of computer microtomography, however, is the non-invasive observation of the internal structure of the tested material on any chosen plane. One of the analyzed planes is shown in Figure 3. A three-dimensional model of a sample that is "virtually cut" at a distance of about $3 \mathrm{~mm}$ from the face of the weld is used to present the geometry of the defects in the whole length of the direction of the linear motion of the tool.

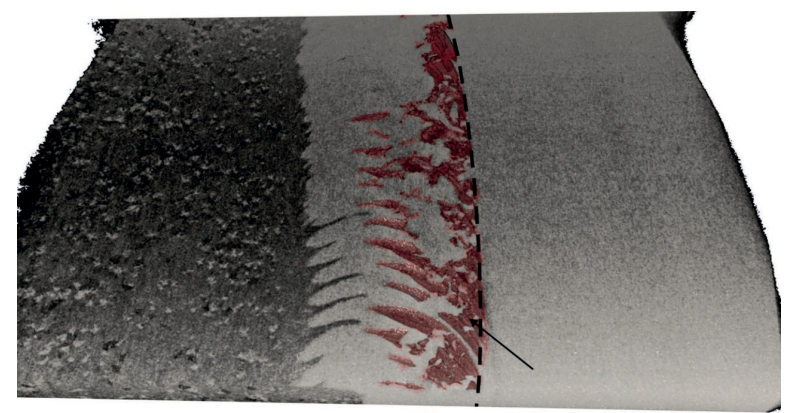

Fig. 3. One analyzed plane - three-dimensional model of sample "virtually cut" at distance of about $3 \mathrm{~mm}$ from face of weld to present geometry of defects in whole length of direction of linear motion of tool

The observation revealed that the defect (indicated by the arrow in Figure 3) is a tunnel that occurs at the retreating side. The tunnel is located along the plane (the border of the direct action of the pin-tool) designated by the movement of the tool. 
The edge of the plane is indicated by the dashed line in Figure 3. The shape of the tunnel varies with the linear movement of the tool, which demonstrates the changing conditions while welding. Furthermore, it can be seen that the defect extends to the weld axis in some areas [17]. As stated in this type of tunnel, defects can be formed as a result of the more rapid movement of the material flow near the face of the weld relative to the lower layers in the weld. Using this form of analysis, we can determine the location of the welding materials in the weld. Figure 3 clearly shows a boundary between the AlSi9Mg material (advancing side) and a section of the weld nugget, which are usually in the FSW joints made of the alloy originating from the retreating side - in this case, it is the 2017A alloy.

Features of X-ray projections allow for further modifications and obtaining images that show only the extracted objects in the three-dimensional image. Such objects are obtained by means of morphological operations performed on the 3D model in the Drishti program. An example of this technique of analysis for test defects is shown in Figure 4. As can be seen in this figure and Figure 5, this is possible to analyze a smaller area of the sample, in addition to obtaining a more precise 3D model of the defect, which in practice means observations at higher magnifications. This is possible thanks to the high resolution scan of the tested sample. Using the characteristics of the image obtained, it was found that the defect (except the tunnel characters) extends towards the axis of the weld in the form of an arc. Because the microtomography research is done in the scale, there are possible distance measurements in the pictures. Using this function, the distances between the arches were measured - these results are summarized in Table 2 .

a)

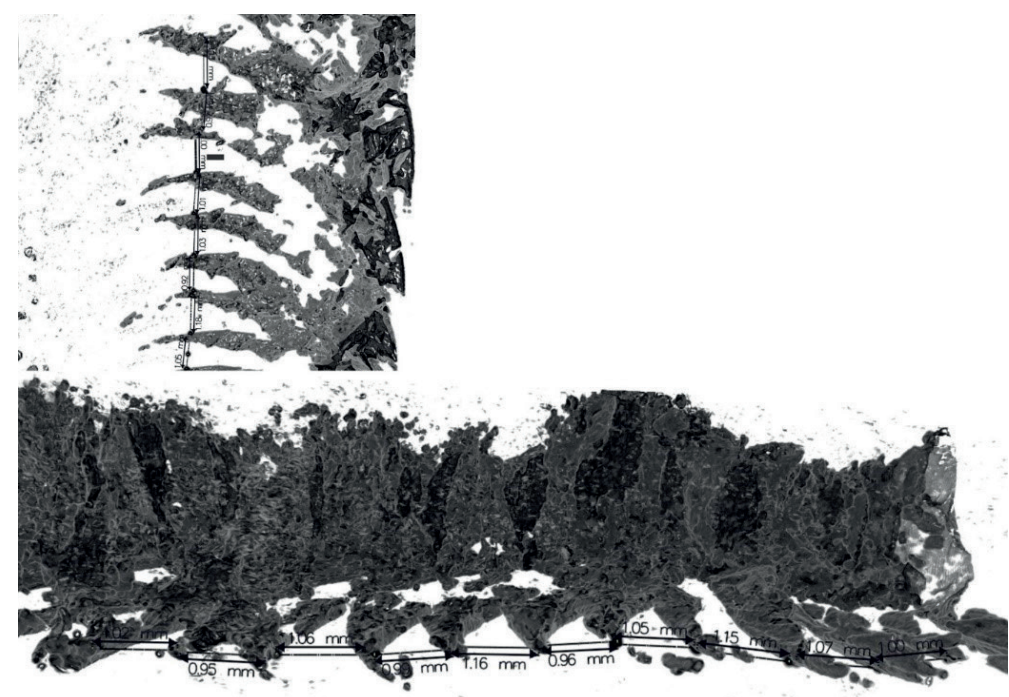

Fig. 4. Three-dimensional model of defect inside AlSi9Mg/2017A weld: a) view from face of weld; b) view along main direction of welding 

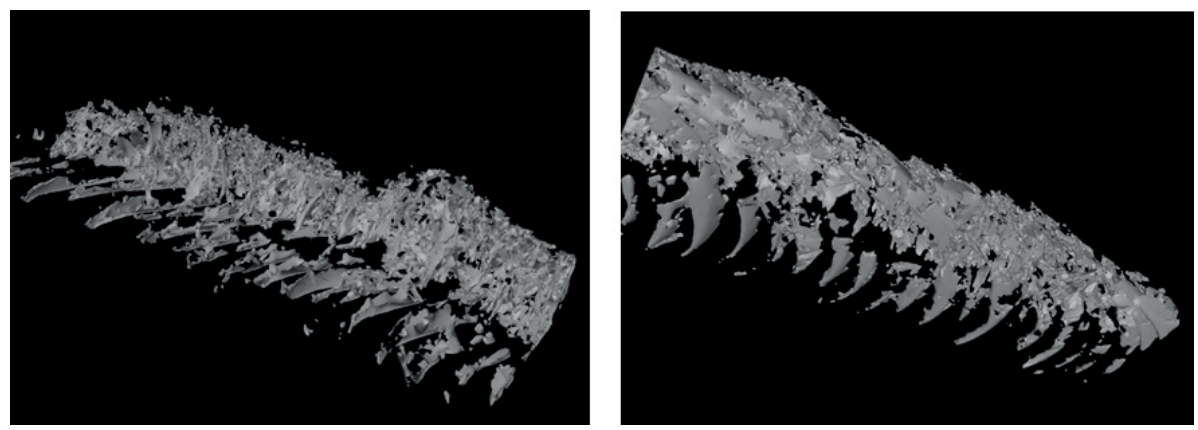

Fig. 5. Extraction of defect from 3D image

Table 2. Distance measurement results of defect passes in form of arc

\begin{tabular}{|l|l|l|l|l|l|l|l|l|l|l|}
\hline $560 / 560$ & 1.00 & 1.07 & 1.15 & 1.05 & 0.96 & 1.16 & 0.99 & 1.06 & 0.95 & 1.02 \\
\hline
\end{tabular}

The distance measurement results show that the defect passes in the form of an arc at about $1 \mathrm{~mm}$. Comparing this value with the parameters of the tool movement, it can be seen that it is formed by one rotation of the tool. When there is a linear velocity of $560 \mathrm{~mm} / \mathrm{min}$ and a rotation rate of $560 \mathrm{rpm}$, the tool performs one rotation during a linear displacement of about $1 \mathrm{~mm}$.

As demonstrated in the above microtomography, analysis can be very useful when examining dissimilar FSW welds. The range of possible performance analyses is very broad and far beyond conventional metallographic methods.

\section{Summary}

Based on the analysis of the microstructure and 3D model, the following points were established:

- Using three-dimensional models created by computed microtomography, it is possible to visualize the internal structure and topography of the surface of a 2017A/ AlSi9Mg aluminum alloy weld.

- Observation of the structure can be carried out at any desired cross-sectional area of the weld.

- Drishti software allows us to perform operations on a three-dimensional model, allowing the extraction of selected structural elements of a weld (in this case, a tunnel defect).

- The measuring tools of the Drishti program enable us to determine the geometrical parameters defects.

- On the basis of our research have shown a close relationship between the defect form and the motion parameters of the tool. 


\section{Acknowledgements}

The FSW process was performed by Dr. Eng. Adam Pietras at the Institute of Welding in Gliwice, Poland.

\section{References}

[1] Kalemba I., Kopyściański M., Hamilton C., Dymek S.: Natural Aging Behavior of Friction Stir Welded Al-Zn-Mg-Cu Aluminum Alloys. Archives of Metallurgy and Materials, 60 (2015), 875-879

[2] Kopyściański M., Dymek S., Hamilton C., Węglowska A., Pietras A., Szczepanek M.: Microstructure of Friction Stir Welded Dissimilar wrought 2017A and cast AISi9Mg Aluminum Alloys. Acta Physica Polonica A, 131 (2017), 1390-1393

[3] Khodir S.A., Morisada Y., Ueji R., Fujii H.: Microstructures and mechanical properties evolution during friction stir welding of SK4 high carbon steel alloy. Materials Science and Engineering A, 558 (2012), 572-578

[4] Rajakumar S., Balasubramanian V.: Correlation between weld nugget grain size, weld nugget hardness and tensile strength of friction stir welded commercial grade aluminium alloy joints. Materials \& Design, 34 (2012), 242-251

[5] Murshid Imam, Kajal Biswas, Vikranth Racherla: Effect of weld morphology on mechanical response and failure of friction stir welds in a naturally aged aluminium alloy. Materials \& Design, 44 (2013), 23-34

[6] Chen C.M., Kovacevic R.: Joining of Al 6061 alloy to AISI 1018 steel by combined effects of fusion and solid state welding. International Journal of Machine Tools and Manufacture, 44, 11 (2004), 1205-1214

[7] Chen Yu-hua, Ni Quan, Ke Li-ming: Interface characteristic of friction stir welding lap joints of Ti/Al dissimilar alloys. Transactions of Nonferrous Metals Society of China, 22, 2 (2012), 299-304

[8] Shah L.H., Othman N.H., Gerlich A.: Review of research progress on aluminium-magnesium dissimilar friction stir welding. Science and Technology of Welding \& Joining, 23, 6 (2018), 256-270

[9] Hamilton C., Dymek S., Dryzek E., Kopyściański M., Pietras A., Węglowska A., Wróbel M.: Application of positron lifetime annihilation spectroscopy for characterization of friction stir welded dissimilar aluminum alloys. Materials Characterization, 132 (2017), 431-436

[10] Hamilton C., Kopyściański M., Węglowska A., Pietras A.: Modeling, microstructure, and mechanical properties of dissimilar 2017A and 5083 aluminum alloys friction stir welds. Proceedings of the Institution of Mechanical Engineers, Part B: Journal of Engineering Manufacture, 233, 2 (2017), 553-564, doi: 10.1177/0954405417740923

[11] Mishra R.S., Ma Z.Y.: Friction stir welding and processing. Materials Science and Engineering: R: Reports, 50, 1-2, (2005), 1-78

[12] Mroczka K.: Characteristics of AlSi9Mg/2017A aluminum alloys friction stir welded with offset welding line and root-side heating. Archives of Metallurgy and Materials, 59, 4 (2014), 1293-1299

[13] Mroczka K., Wójcicka A., Pietras A.: Characteristics of dissimilar FSW welds of aluminum alloys 2017A and 7075 on the basis of multiple layer research. Journal of Materials Engineering and Performance, 22, 9 (2013) 2698-2705

[14] Prashant Chauhan, Rahul Jain, Surjya K. Pal, Shiv B. Singh: Modeling of defects in friction stir welding using coupled Eulerian and Lagrangian method. Journal of Manufacturing Processes, 34A (2018), 158-166

[15] Hamade R.F., Baydoun A.M.R.: Nondestructive detection of defects in friction stir welded lap joints using computed tomography. Materials \& Design, 162 (2019), 10-23

[16] http://sf.anu.edu.au/Vizlab/drishti/help.shtml

[17] Gratecap F., Girard M., Marya S., Racineux G.: Exploring material flow in friction stir welding: tool eccentricity and formation of banded structures. International Journal of Material Forming, 5, 2 (2015), 99-107 